\title{
Teacher's Views on Distance Education in Turkish Teaching
}

\author{
Cahit EPÇAÇAN ${ }^{1} \quad$ İlknur PAÇALI ${ }^{2}$
}

\author{
Gönderim Tarihi: 15.09.2021
}

Kabul Tarihi: 15.10 .2021

Yayın Tarihi: 19.10 .2021

\begin{abstract}
This study has been designed to examine practices in distance education in terms of Turkish teaching in line with the teachers' views. This study is a case study. The study group consists of 25 Turkish teachers working in various secondary schools in the province of Siirt. The semi-structured interview form was used as a data collection tool. The data were analysed via the content analysis method through the Maxqda Qualitative Analysis program. The findings revealed that the activities regarding listening, speaking, and reading skills as part of the Turkish teaching lesson in distance education were productive, but little improvement was observed in writing skills and there were problems such as lack of equal opportunities and disruptions arising from technological infrastructure. It was also observed that students with opportunities had more interest in lessons. In the South-eastern Anatolia Region, where it is very difficult to apply distance education, teachers continue to encourage students in both digital and face-to-face environments to prevent the interruption of education.
\end{abstract}

Keywords: Turkish Teaching, Distance Education, Turkish Lessons.

\section{Türkçe Öğretiminde Uzaktan Eğitime Yönelik Öğretmen Görüşleri}

Öz: Bu araştırmanın amacı Türkçe öğretiminde yapılan uzaktan eğitim çalışmalarını öğretmen görüşleri doğrultusunda incelemektir. Bu çalışma, nitel araştırma yöntemlerinden durum çalışması deseninde tasarlanmıştır. Araştırmanın çalışma grubu, Siirt ilinde çeşitli ortaokullarda görev yapan 25 Türkçe öğretmeninden oluşmaktadır. Veri toplama aracı olarak yarı yapılandırılmış görüşme formu kullanılmıştır. Elde edilen veriler, Maxqda Nitel Analiz programı aracılığıyla içerik analizi yöntemi kullanılarak çözümlenmiştir. Araştırma bulguları kapsamında; Türkçe öğretiminde yapılan uzaktan eğitim faaliyetlerinde dinleme, konuşma ve okuma beceri alanıla ilgili çalışmaların verimli geçtiği fakat yazma beceri alanında eksiklikler olduğu; öğrencilerin eşit imkânlara sahip olamaması ve teknolojik alt yapı eksiklerinin uzaktan eğitim sürecini aksattığı fakat bu koşullara sahip olan öğrencilerin Türkçe dersine yönelik ilgilerinin arttığı sonucuna ulaşılmıştır. Uzaktan eğitimi gerçekleştirmeye yönelik şartları sağlamanın oldukça zor olduğu Güneydoğu Anadolu Bölgesi'nde eğitimin aksamaması adına öğretmenlerin, hem çevrimiçi hem de yüz yüze ortamlarda öğrencileri teşvik edici çalışmalar öne sürdürdüğ̈̈ görülmüştür.

Anahtar Kelimeler: Türkçe Öğretimi, Uzaktan Eğitim, Türkçe Dersi.

\section{INTRODUCTION}

In the wake of advances in technology, not only a great number of issues in life have been affected but also various transformations have been observed in education depending on the possibilities of time. With the emergence of digital systems and the development of internet technology, time and space limits have disappeared in the field of education, and thus, educational environments that support face-to-face training have been launched (Kırık, 2014). This mobility in educational practices has paved the way for the use of concepts such as e-learning, web learning, web 2.0 tools, online education, and distance education in addition to the previous education concepts, which have attained a place in the literature (Demir, 2014). Distance education is a teaching method in which communication and interaction between students and those who plan educational activities and practitioners are provided from a specific centre through specially-prepared teaching units and various environments, in cases where it is not possible to carry out classroom activities due to the limitations of traditional teaching-learning methods (Alkan, 1987). The foundations of the concept of distance education date back to old times. The first known use of distance education was observed

\footnotetext{
1 Siirt Üniversitesi, Türkiye, epcacan@siirt.edu.tr, ORCID: 0000-0002-8090-4442.

2 Siirt Üniversitesi, Türkiye, ilknur.pacali@siirt.edu.tr, ORCID: 0000-0002-3847-1903.
} 
found on the advertisement placed in the Boston Gazette on March 20, 1728, for "Shorthand Lessons" (Holmberg, 2008). Then, in 1833, "Composition Lessons through Mails" were given to women at the University of Sweden, and thus, the transition to distance education activities by correspondence and letters in different countries of the world accelerated. The establishment of the Open University in England in 1969, which was a result of the use of radio and television in education from the late 1960 s to the 1980s and the increasing demand for higher education, triggered the change of distance education all over the world (Göçer, 2021). Distance education practices in Turkey, which were launched as a result of such developments, are examined based on three main periods: Conceptualization process, correspondence education process, and the use of communication technologies (İssman, 2011: 107). Between the years 1927 and 1955, the process of distance education by letter was brought to the agenda to make the people literate; however, because of the belief that reading and writing cannot be taught with distance education without a teacher, these ideas remained conceptual without concrete implementation (Gelişli, 2015).

The first practices for distance learning were launched following correspondence education activities in the second phase of distance education in Turkey. These practices encompass the followings: education through mails at the Faculty of Law, Banking and Commercial Law Research Institute, Ankara University provided to employees in banks in 1956, "correspondence education" activities carried out by the Ministry of National Education in 1960, the establishment of the "Directorate of Correspondence Education and Technical Publications" in 1966, and the affiliation of the Correspondence Education Centre to the Non-formal Higher Education Institution (YAYKUR) (Kaya, 2002). Following such practices, it was concluded that distance education conducted solely with printed materials was not sufficient, and correspondence education was replaced by the use of communication technologies (İşman, 2011).

The use of communication technologies in distance education as part of the third period is divided into two sections as the use of audio-visual tools (1976-1995) and the information-based period (Göçer, 2021). TRT (Turkish Radio and Television Corporation) started broadcasting about education in 1968 in Turkey (Aziz, 1982) while in 1973 the Education Centre through Film, Radio, and Television and the Ministry of National Education launched the broadcasting of educational programs covering primary, secondary, and high schools, and this set the ground for incorporating higher education into the process. The Open Education Faculty, which was established in 1982, led to the prevalence of courses together with radio and television channels.

Following the addition of Open Education High School courses to these broadcasts in 1992, the TRT4 channel was devoted to education (İşman, 2011). Then, after the rapid advancement of technology and universities started to purchase equipment for distance education, various programs run with distance education were established in higher education institutions such as Anadolu University, Sakarya University, Istanbul University, Marmara University, Kocaeli University, İnönü University, and Hoca Ahmet Yesevi International Kazakh-Turkish University. It is known that the studies in the field of Information and Communication Technologies (ICT) in the late 1990s and early 2000s laid the groundwork for the developments in the field of education. The "FATIH Project" implemented by the Ministry of National Education (MEB) in 2012 is the most concrete step taken to digitize the Turkish education system (Ateş ve Sur, 2021). The aim of this project is to provide smart boards, tablet computers, and internet infrastructure to all schools in basic education to increase equality of opportunity in education. The Education Information Network (EBA), established within the scope of the Fatih project, includes lectures, questions, assignments, and various digital contents related to each course. With this project, distance education studies have begun to appeal to a wider 
educational audience and have been applied at various educational levels.

Distance education, which is an interdisciplinary field that tries to eliminate the limitations between learner, teacher, and learning resources and uses existing technologies with a pragmatist approach to achieve this, ensures the continuity of education in cases where face-to-face education is not possible (Bozkurt, 2017: 86). After education was suspended due to the earthquakes having occurred in Van, Malatya, and Elazig a few years ago, the active use of the Education Information Network (EBA) was put into use by the Ministry to prevent the interruption of education. This temporary practice continued in Turkey following the suspension of all education levels in March 2020 due to the Covid-19 outbreak. It is observed that practices and research for distance education in the Turkish education system have increased significantly as a result of such unprecedented developments. Although teaching Turkish covers basic language skills, it is one of the main courses of education. The adaptation of Turkish language teaching studies conducted within the Ministry of National Education to distance education and its development should be evaluated within the education system. In this respect, examining the distance education studies in the field of Turkish education and teaching and describing the existing situations will contribute to the development of Turkish teaching. The goal of this study is to examine the distance education studies in Turkish teaching in line with the teachers' views. The sub-goals determined in line with this general goal are as follows:

- What is done to improve basic language skills in teaching Turkish in distance education?

- Which practices are used in Turkish teaching in distance education and how?

- What are the contributions of distance education to Turkish teaching?

- What are the limitations of distance education in Turkish teaching?

- What can be done to improve Turkish teaching in distance education?

\section{METHOD}

Aiming to examine teachers' views on distance education in Turkish teaching, this study was designed based on the case study pattern, which is one of the qualitative research methods. Providing an intensive description and analysis of a limited system (Merriam, 2013), case studies aim to investigate a contemporary phenomenon (the 'case') in depth and within its real-world context where the boundaries between an event and a context are not clear (Yin, 2014). The case of this study is "teachers' views on distance education in Turkish teaching". In order for the case studies to be better understood by the reader or the relevant individuals, the content of the study should be clearly explained by illustrating all the concepts related to the case (Saban \& Ersoy, 2016) (Baxter \& Jack, 2008). To reveal the understanding of the study and determine its limits, the relevant cases were determined as follows (See Figure 1). 


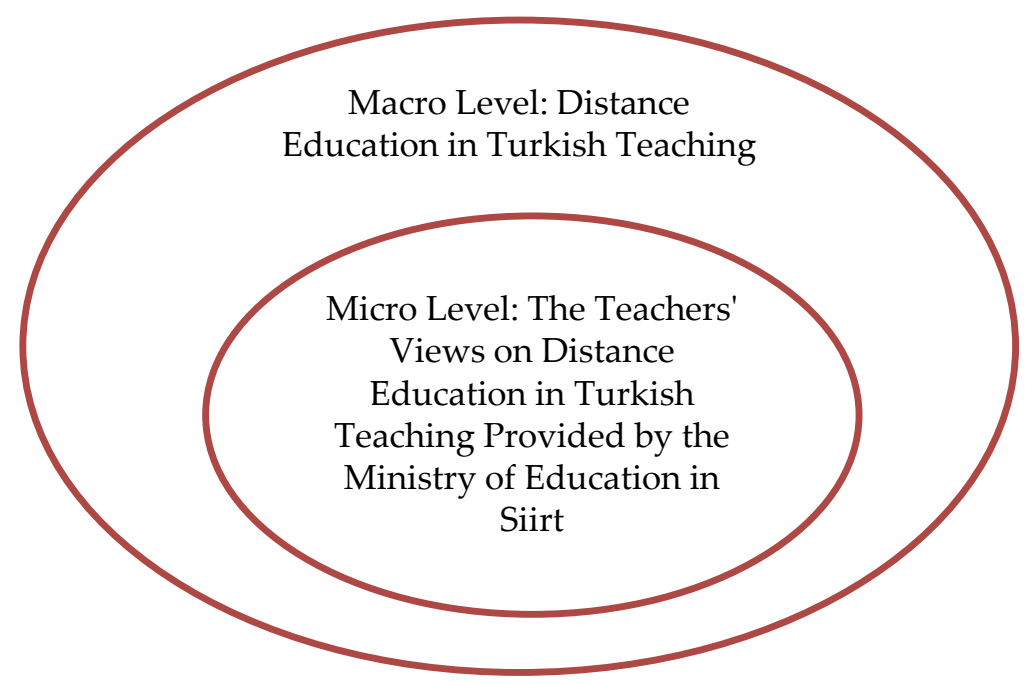

Figure 1. Definition of the Case in the Study

\section{Study Group}

In this study, the purpose of obtaining data within the framework of the micro-level case was taken as a basis while creating the study group. In this context, the study group was determined by the criterion sampling method, one of the purposeful sampling methods. Criterion sampling is the study of cases that meet a predetermined set of criteria (Yıldırım \& Şimşek, 2013). The criterion that determines the participants of this study is to be teaching Turkish in the secondary schools affiliated with the Ministry of Education in Siirt. Also, Turkish teachers were supposed to be involved in the distance education process in line with the purpose of the study. The study group determined in line with these criteria consists of 25 Turkish teachers working in the secondary schools affiliated with the Ministry of Education in Siirt.

\section{Data Collection}

Research data were collected using a semi-structured interview form. The steps followed while creating the data collection tool of the research (Semi-Structured Interview Form for the Evaluation of Distance Education in Turkish Teaching) are as follows: reviewing the literature on the subject, preparing questions suitable for the sub-goals of the research, developing questions in line with the relevant literature review, determining research questions, receiving expert opinion, creating the final version after restructuring the interview form in line with pilot scheme and feedbacks. While preparing the data collection tool, the opinions of 3 experts were received and a pilot scheme was conducted with 2 Turkish teachers. As a result of the pilot scheme, the interview form was rearranged and the scheme was launched.

\section{Data Analysis}

In the analysis of the data obtained in this study, the Maxqda qualitative analysis program was used. Descriptive and content analysis techniques were used while analysing the data. Descriptive analysis is a form of analysis in which the obtained data is summarized and interpreted based on previously determined themes and conceptual framework (Yıldırım \& Şimşek, 2016). Content analysis is a method that enables similar data to be transformed into themes with certain expressions and concept patterns and to help interpret by organizing them in an understandable way (Usluel \& Mazman, 2010). The research data were first examined in a general way with the descriptive analysis 
technique, and then the responses given to each interview question were analysed and encoded with the content analysis technique. The codes obtained from the study were categorized and themes were created. As a result of the analysis, 345 codes, 42 categories, and 5 themes were obtained from the interview forms of 25 participants.

\section{Validity and Reliability Studies of The Research}

In order to ensure the internal validity (credibility) of the study, opinions of 2 academic staff were received on the findings of the study. To increase the external validity (transferability) of the research, all the steps of the qualitative research process were described in detail and the confirmability of the case under consideration with different cases was increased. Opinions of 3 experts were received for the analysis made to ensure the reliability of the study.

\section{FINDINGS}

The findings were collected under 5 themes in accordance with the sub-goals of the study. The themes created during the analysis of the data are presented below respectively.

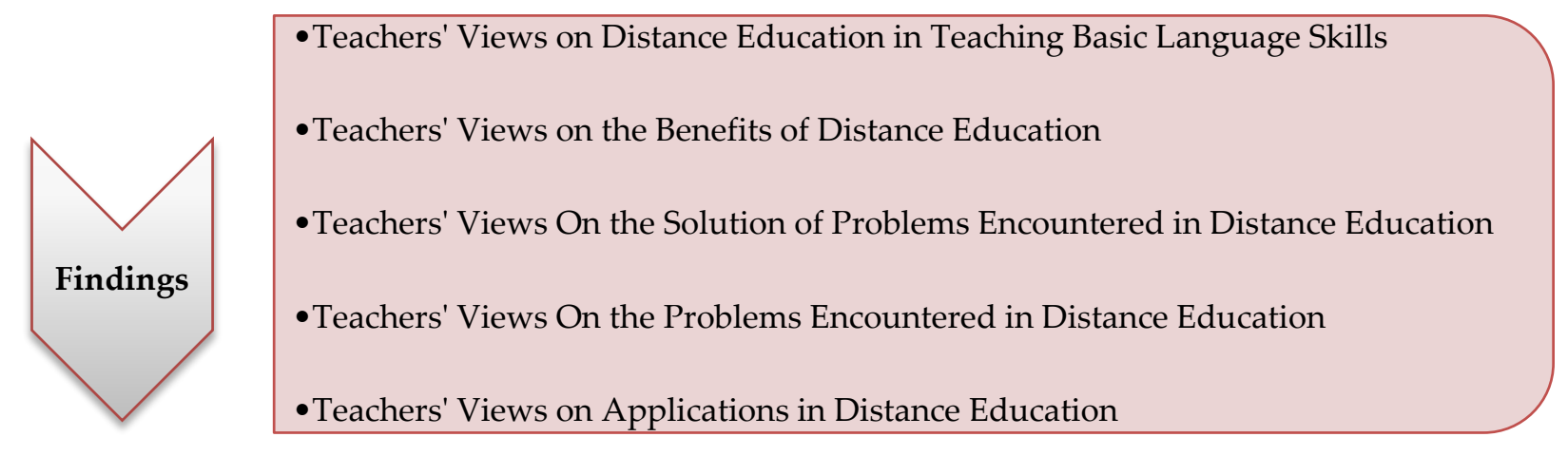

Figure 2. Findings Regarding Teachers' Views on Distance Education in Turkish Teaching

\section{Teachers' Views on Distance Education in Teaching Basic Language Skills}

The Turkish teachers who participated in the study were asked what they think about teaching the basic language skills (reading, speaking, listening, and writing) in the Turkish lesson within the scope of distance education. Data codes and categories regarding the responses received from teachers are shown in Table 1.

Table 1. Findings Regarding the Effect of Distance Education Process on the Development of Basic Language Skills

\begin{tabular}{llrrl}
\hline Category & Code & f & \% & Sample Statements \\
\hline Listening & Positive Effect & 16 & 22 & "Listening to tales, stories or poems from audio content and sharing \\
Skill & & & & $\begin{array}{l}\text { inferences with friends contribute to speaking and listening skills } \\
\text { (P8)."In addition, listening to tales, stories or poems from audio } \\
\end{array}$ \\
& & & $\begin{array}{l}\text { content and sharing inferences with friends contribute to speaking } \\
\text { and listening skills (P13)." }\end{array}$ \\
\hline
\end{tabular}




\begin{tabular}{|c|c|c|c|c|}
\hline & Negative Effect & 4 & 5 & $\begin{array}{l}\text { "I do not think this is an effective communication for listening and } \\
\text { speaking (P17)." "Internet outage is a problem sometimes. I am } \\
\text { having much trouble with listening to the texts and finding it } \\
\text { difficult to listen to the texts that we listen to more than once in } \\
\text { lessons via distance education. Children hardly understand (P20)." }\end{array}$ \\
\hline \multirow[t]{2}{*}{$\begin{array}{l}\text { Reading } \\
\text { Skill }\end{array}$} & Positive Effect & 9 & 12.5 & $\begin{array}{l}\text { "I have a scheduled reading hour and interview book interviews at } \\
\text { home for the acquisition of reading skill (P6)." "I do not have much } \\
\text { trouble in reading skills in Turkish teaching. When I assign the } \\
\text { reading text to the students in a systematic way, the children read } \\
\text { in turn (P25). }\end{array}$ \\
\hline & Negative Effect & 8 & 11 & $\begin{array}{l}\text { "You can forget or regress in reading and writing (P15)." As } \\
\text { writing and reading are the least used skills, it becomes quite } \\
\text { difficult to make Turkish lessons efficient (P1)." }\end{array}$ \\
\hline \multirow[t]{2}{*}{$\begin{array}{l}\text { Speaking } \\
\text { Skill }\end{array}$} & Positive Effect & 9 & 12.5 & $\begin{array}{l}\text { "Children can listen to a fairy tale and talk about it for minutes } \\
\text { (P4)." "If distance education content is composed of entertaining } \\
\text { activities and consists of a rich curriculum directly related to the } \\
\text { field of speech, then children will benefit from such activities and } \\
\text { express themselves more efficiently (P10)." }\end{array}$ \\
\hline & Negative Effect & 9 & 12.5 & $\begin{array}{l}\text { "In particular since there is little interaction with students, learning } \\
\text { remains incomplete (insufficient time and participation) and } \\
\text { writing and speaking activities fall short (P19)." I think that my } \\
\text { students with difficulties in writing and speaking due to local } \\
\text { conditions, their skills lie fallow in distance education (P14)." }\end{array}$ \\
\hline \multirow[t]{2}{*}{$\begin{array}{l}\text { Writing } \\
\text { Skill }\end{array}$} & Positive Effect & 2 & 3 & $\begin{array}{l}\text { "I give writing assignments on various topics, take part in contests } \\
\text { they are involved in, check assignments on WhatsApp application } \\
\text { or provide feedback (P7)." "I usually use are the applications on } \\
\text { reading, listening, writing, and speaking (P9)." }\end{array}$ \\
\hline & Negative Effect & 15 & 21 & $\begin{array}{l}\text { "I need more effective activities for those who are not proficient in } \\
\text { writing. Some of my students commit spelling errors, which I } \\
\text { believe must be due to the decrease in writing activities (P2)." }\end{array}$ \\
\hline TOTAL & & 72 & 100 & \\
\hline
\end{tabular}

The Turkish teachers participating in the study stated that while the activities on listening, speaking, and reading skills were productive in distance education, writing skills, whose success rate decreased due to the difficulty of checking students' writing assignments, were problematic.

\section{Teachers' Views on Applications in Distance Education}

The Turkish teachers participating in the study were asked about online applications they used in distance education. Data codes and categories related to the responses are shown in Table 2. 
Table 2. Findings Regarding Applications Used in Distance Education

\begin{tabular}{|c|c|c|c|c|}
\hline Category & Code & $\mathbf{f}$ & $\%$ & Sample Statements \\
\hline \multirow[t]{2}{*}{$\begin{array}{l}\text { Lesson } \\
\text { Management } \\
\text { Systems }\end{array}$} & Zoom & 11 & 26 & $\begin{array}{l}\text { "I carry out all synchronous lessons through the Zoom application } \\
\text { (P12)." "I am giving online lessons through the Zoom application } \\
\text { (P23)." }\end{array}$ \\
\hline & $\begin{array}{l}\text { Smart } \\
\text { Board }\end{array}$ & 1 & 2 & "I am also making use of smart board (P1)." \\
\hline \multirow[t]{3}{*}{$\begin{array}{l}\text { Instructional } \\
\text { Web Pages } \\
\text { and Software }\end{array}$} & $\begin{array}{l}\text { Morpa } \\
\text { Kampüs }\end{array}$ & 5 & 12 & $\begin{array}{l}\text { "I use Morpa Kampüs contents to reinforce learning (P22)." } \\
\text { "Through exercises and problem-solving activities in Morpa } \\
\text { Kampüs and Okulistik, I make sure that students understand the } \\
\text { subject well (P14)." }\end{array}$ \\
\hline & $\begin{array}{l}\text { Web } 2 \\
\text { Tools }\end{array}$ & 9 & 21 & $\begin{array}{l}\text { "I use online games related to grammar that I have created with } \\
\text { Web } 2 \text { tools when lessons are inefficient (P3)." II use Okulistik to } \\
\text { ensure students well-understand the subject (P18)." }\end{array}$ \\
\hline & EBA & 8 & 19 & $\begin{array}{l}\text { "I use the Zoom application, EBA activities, and publishers' z- } \\
\text { books in twenty-five hours of the lesson (P2)." "I use EBA and } \\
\text { Zoom applications } 24 \text { hours a week (P8)." }\end{array}$ \\
\hline $\begin{array}{l}\text { Instant Chat } \\
\text { Applications }\end{array}$ & WhatsApp & 4 & 10 & $\begin{array}{l}\text { "I used WhatsApp to teach at the very beginning of distance } \\
\text { education due to failures in EBA and system problems } \\
\text { (P13)." "Apart from these, I send notes to students on WhatsApp } \\
\text { to allow them to write about the games and the subject in their } \\
\text { notebooks. Finally, we use the application effectively as they send } \\
\text { the summaries of the books assigned on WhatsApp (P24)." }\end{array}$ \\
\hline $\begin{array}{l}\text { Other Digital } \\
\text { Tools and } \\
\text { Applications } \\
\text { Used in } \\
\text { Turkish } \\
\text { Teaching }\end{array}$ & Z- Book & 4 & 10 & $\begin{array}{l}\text { "I mainly use the "Z-book". I use it almost in all lessons (P21)." } \\
\text { "I effectively make use of Z-books (K2)." }\end{array}$ \\
\hline TOTAL & & 42 & 100 & \\
\hline
\end{tabular}

The Turkish teachers report that Zoom and EBA applications were mainly used in distance education. While lectures were carried out with the Zoom program, problem-solving activities were carried out to reinforce learning with EBA, Morpa Kampüs, Z-Books, and various Web 2 tools. The WhatsApp application was also used for planning activities and providing feedback.

\section{Teachers' Views on The Benefits of Distance Education}

The Turkish teachers were asked whether distance education was beneficial to Turkish teaching or not. Data codes and categories regarding the responses are shown in Table 3. 
AJER - Academia Eğitim Araştırmaları Dergisi 2021, 6(2), 508-521

https://dergipark.org.tr/pub/egitim e-ISSN 2619-9351

Table 3. Findings on the Benefits of Distance Education

\begin{tabular}{|c|c|c|c|c|}
\hline Category & Code & f & $\%$ & Sample Statements \\
\hline \multirow[t]{2}{*}{$\begin{array}{l}\text { Participation } \\
\text { in Lessons }\end{array}$} & $\begin{array}{l}\text { Active } \\
\text { Participation }\end{array}$ & 15 & 41 & $\begin{array}{l}\text { "Children generally like and try to participate actively in Turkish } \\
\text { lessons (P20)"“All of the students with internet access actively } \\
\text { participated in my lessons (P8)." }\end{array}$ \\
\hline & Willingness & 10 & 27 & $\begin{array}{l}\text { "The use of instructional technologies in the Turkish lesson as in } \\
\text { every lesson will be very beneficial. Secondary school students" } \\
\text { ability to learn by having fun makes it essential to use technology, } \\
\text { especially in the distance education process. Preparing games about } \\
\text { the subject for students will increase the efficiency of the lesson as } \\
\text { well as increase their desire to learn (P23)." They were competing } \\
\text { among themselves to take the floor and answer the questions (P2)." }\end{array}$ \\
\hline $\begin{array}{l}\text { Lesson } \\
\text { Materials }\end{array}$ & $\begin{array}{l}\text { Increased } \\
\text { Diversity }\end{array}$ & 3 & 8 & $\begin{array}{l}\text { "I use online games about grammar that I have created with Web } 2 \\
\text { tools when I feel the lesson is not going well (P6)." "It provides easy } \\
\text { access to e-books and tests (P9)." }\end{array}$ \\
\hline \multirow[t]{4}{*}{$\begin{array}{l}\text { Effects on } \\
\text { Students }\end{array}$} & $\begin{array}{l}\text { Increasing } \\
\text { Self } \\
\text { confidence }\end{array}$ & 3 & 8 & $\begin{array}{l}\text { "I noticed that my students constantly attend the lesson. Some of } \\
\text { these students were actually students who were not very active in } \\
\text { the lesson during face-to-face education. I think they gained self- } \\
\text { confidence as the camera was off. They almost compete among } \\
\text { themselves to take the floor and answer the questions. I think they } \\
\text { have improved their communication skills (P2)" }\end{array}$ \\
\hline & $\begin{array}{l}\text { Drawing } \\
\text { Attention }\end{array}$ & 3 & 8 & $\begin{array}{l}\text { "I do not hear anyone saying the lesson is boring. On the contrary, } \\
\text { almost all of the attendees report that synchronous lessons are very } \\
\text { enjoyable. I believe that the most important reason for this is that } \\
\text { interactive activities are sufficient enough to give each student } \\
\text { enough time to answer and that visual and auditory sources attract } \\
\text { morer attention } \\
\text { "Students become more concentrated. Most of the activities } \\
\text { (activities such as reading, telling, completing stories, presentation) } \\
\text { can also be done digitally (P19)." }\end{array}$ \\
\hline & $\begin{array}{l}\text { Arousing } \\
\text { Interest }\end{array}$ & 2 & 5 & $\begin{array}{l}\text { "I got positive feedback. They report that students who normally do } \\
\text { not like Turkish lessons have more interest now (P6)." "Only 10-15 } \\
\text { of the students attend the lesson due to financial difficulties. The } \\
\text { interests and attitudes of the students who attend the lesson } \\
\text { towards the Turkish lesson are better now (P13)." }\end{array}$ \\
\hline & $\begin{array}{l}\text { Easy Access } \\
\text { to } \\
\text { Information }\end{array}$ & 1 & 3 & $\begin{array}{l}\text { "I consider it important for students and teachers to have access to } \\
\text { information a short time (P8)." }\end{array}$ \\
\hline TOTAL & & 37 & 100 & \\
\hline
\end{tabular}

The Turkish teachers who participated in the study, distance education studies positively affect the participation process of my students in case the necessary infrastructure is provided. In fact, students failing to attend lessons due to lack of self-confidence and timidity during face-to-face education can feel more comfortable on these platforms. In addition, students' ease of access to information and the variety of materials contribute to the consolidation of the subject. 


\section{Teachers' Views on The Problems Encountered in Distance Education}

The Turkish teachers participating in the study were asked whether they encountered a problem in Turkish teaching during the distance education process. Data codes and categories regarding the responses are shown in Table 4.

Table 4. Findings Regarding the Problems Encountered in Turkish Teaching in Distance Education

\begin{tabular}{|c|c|c|c|c|}
\hline Category & Code & $f$ & $\%$ & Sample Statements \\
\hline \multirow[t]{3}{*}{$\begin{array}{l}\text { Lack of } \\
\text { Equipment }\end{array}$} & $\begin{array}{l}\text { Lack of } \\
\text { Technological } \\
\text { Equipment }\end{array}$ & 25 & 37 & $\begin{array}{l}\text { "Unfortunately, it is a great disadvantage that our students living } \\
\text { in the villages cannot follow the lessons and do not have the } \\
\text { opportunity to access the activities designed for them (P2)." "Yes, } \\
\text { there is participation by students. Thus, the biggest problem is that } \\
\text { students do not have an internet connection or devices } \\
\text { (smartphone, tablet, and computer) to participate in the lesson } \\
\text { (P4)." }\end{array}$ \\
\hline & $\begin{array}{l}\text { Internet } \\
\text { Connection } \\
\text { Problems }\end{array}$ & 18 & 26 & $\begin{array}{l}\text { "The main problem is the internet connection (P16)." "Of course, } \\
\text { I had to provide feedback frequently due to problems regarding the } \\
\text { internet connection (P15)." "Students cannot concentrate in } \\
\text { listening and speaking skills due to freezing and disconnection } \\
\text { problems caused by the internet (P18)." }\end{array}$ \\
\hline & $\begin{array}{l}\text { Power } \\
\text { Blackout }\end{array}$ & 3 & 4 & $\begin{array}{l}\text { "The power blackout is a problem (P10)." It is common to observe } \\
\text { power blackouts in the region I live, which also interrupts distance } \\
\text { education (P11)." }\end{array}$ \\
\hline
\end{tabular}

\begin{tabular}{|c|c|c|c|c|}
\hline & $\begin{array}{l}\text { Inconvenient } \\
\text { Study } \\
\text { Environment at } \\
\text { Home }\end{array}$ & 2 & 3 & $\begin{array}{l}\text { "Also the family environment is a problem -i.e. crying baby or } \\
\text { misbehaviours, etc.- (P14)." "Such problems hinder students from } \\
\text { having a quiet environment where they can focus on lessons (P4)." }\end{array}$ \\
\hline $\begin{array}{l}\text { Education } \\
\text { System }\end{array}$ & $\begin{array}{l}\text { Long Lesson } \\
\text { Hours }\end{array}$ & 2 & 3 & $\begin{array}{l}\text { "35 hours of distance education for students is not pedagogically } \\
\text { appropriate (P7)." }\end{array}$ \\
\hline Parents & $\begin{array}{l}\text { Parental } \\
\text { Indifference }\end{array}$ & 14 & 21 & $\begin{array}{l}\text { "We had problems with some parents in distance education. It is } \\
\text { possible to see those who think that the teachers are responsible for } \\
\text { the suspension of schools and that distance education will not } \\
\text { work at all, or that messages and assignments will work } \\
\text { (P22)." Some parents contacted neither the teacher nor the school. } \\
\text { Aside from the lessons of the children, they did not even deal with } \\
\text { us, saying that distance education does not work anyway (P20)." }\end{array}$ \\
\hline \multirow[t]{2}{*}{ Student } & Readiness & 1 & 2 & $\begin{array}{l}\text { "Few students participate in lessons (economic reasons). There is } \\
\text { a lack of knowledge and awareness (students are unaware of and } \\
\text { uninterested in distance education, and unable to use it) (P12)." }\end{array}$ \\
\hline & $\begin{array}{l}\text { Failing to be } \\
\text { responsible }\end{array}$ & 3 & 4 & $\begin{array}{l}\text { "In a ten-person online lesson, the number drops from five to four } \\
\text { after five minutes, and this inevitably disrupts the teacher } \\
\text { motivation (P17)." In the early days of distance education, some } \\
\text { students were abusing the lesson because of inability to use the } \\
\text { Zoom program (P24)." }\end{array}$ \\
\hline TOTAL & & 68 & 100 & \\
\hline
\end{tabular}

The Turkish teachers report that the biggest problem experienced in the distance education process was the lack of infrastructure. The lack of internet access and technological devices such as tablets, computers, and smartphones had negative impacts on the process. Due to inequality of opportunity, students cannot participate in educational activities and fall behind in lessons. This makes it difficult 
for teachers to control the process.

\section{Teachers' Views on The Solution of Problems Encountered in Distance Education}

The Turkish teachers participating in the study were asked about suggestions they could make to solve the problems encountered in Turkish teaching in distance education. Data codes and categories regarding the responses are shown in Table 5.

Table 5. Findings Regarding the Solution of Problems Encountered in Turkish Teaching in Distance Education

\begin{tabular}{|c|c|c|c|c|}
\hline Category & Code & $f$ & $\%$ & Sample Statements \\
\hline \multirow[t]{6}{*}{$\begin{array}{l}\text { Prospective } \\
\text { Suggestions }\end{array}$} & $\begin{array}{l}\text { Supply of } \\
\text { Technological } \\
\text { Tools }\end{array}$ & 16 & 25 & $\begin{array}{l}\text { "The necessary infrastructure should be provided to increase } \\
\text { participation (P10)." There should be equality of opportunity } \\
\text { for students (P17)." "All students should be given tablets. Thus, } \\
\text { problems may be solved at least for my students (P3)." }\end{array}$ \\
\hline & $\begin{array}{l}\text { Solution of } \\
\text { Technical } \\
\text { Problems }\end{array}$ & 13 & 20 & $\begin{array}{l}\text { "Students should be provided with technological opportunities } \\
\text { and access to the internet at any time (P11)." "Such equipment } \\
\text { should be reached to a maximum number of students (P23)." }\end{array}$ \\
\hline & $\begin{array}{l}\text { Increasing the } \\
\text { Quality of } \\
\text { Materials }\end{array}$ & 6 & 8 & $\begin{array}{l}\text { "Digital contents should be diversified (P18)." I think } \\
\text { instructional technologies will make a positive contribution to } \\
\text { Turkish teaching. Activities can be adapted to education through } \\
\text { visualization and gamification (P13)." }\end{array}$ \\
\hline & $\begin{array}{l}\text { Distance } \\
\text { Education Seminar } \\
\text { for Students and } \\
\text { Parents }\end{array}$ & 2 & 3 & $\begin{array}{l}\text { "All stakeholders should be provided with information and } \\
\text { seminars should be held for distance education (P3)." }\end{array}$ \\
\hline & $\begin{array}{l}\text { Remedial } \\
\text { Teaching }\end{array}$ & 1 & 2 & $\begin{array}{l}\text { "I think that if schools reopen, remedial teaching should be } \\
\text { provided especially for these students (P2)." }\end{array}$ \\
\hline & $\begin{array}{l}\text { Face-to-face } \\
\text { Education } \\
\text { Preference }\end{array}$ & 2 & 3 & $\begin{array}{l}\text { "Face-to-face education should continue even during the } \\
\text { pandemic, albeit limited. It has been understood that distance } \\
\text { education can be an aid but cannot serve as a substitute for a } \\
\text { teacher (P19)." "Contrary to what is believed in the society, } \\
\text { teaching Turkish does not consist of only grammar teaching and } \\
\text { is better taught with face-to-face applications, and thus no } \\
\text { matter how effective the distance education process is carried } \\
\text { out, it will not fully reach its goal (P21)." }\end{array}$ \\
\hline $\begin{array}{l}\text { Solutions for } \\
\text { the } \\
\text { Improveme } \\
\text { nt of the } \\
\text { Process }\end{array}$ & $\begin{array}{l}\text { The effort of } \\
\text { Adaptation by } \\
\text { the Teacher }\end{array}$ & 16 & 25 & $\begin{array}{l}\text { "To deal with this problem, I prepared a lecture video, } \\
\text { transferred it to flash media, and gave it to students. This is what } \\
\text { I found as a solution (P18)." "I think that especially teachers who } \\
\text { were previously incapable in computer and digital applications } \\
\text { have improved themselves as a result of the process (P4)." }\end{array}$ \\
\hline
\end{tabular}




$\begin{array}{lll}\text { Supply of } & 5 & 7 \\ \text { Resources } & & \end{array}$

"I encountered many problems, but the biggest one was that I could not reach many of our students due to financial difficulties. Likewise, I tried to reach my students who could not attend synchronous lessons due to financial difficulties via WhatsApp. I was with my students by calling them to the school and trying to minimize this problem by giving notes and test books to use in this process (P16)." "While they have equal conditions at school, this is not possible in distance education. I prepare documents that I can deliver to all of them by asking them to visit me at school (P20)."

Involving Parents $4 \quad 6 \quad$ "I organize reading hours with my students who read regularly in the Process and who read the same book with their parents (P18)." "In distance education, I endeavoured to deliver the weekly homework prepared by the national education to the parents (P14)."

TOTAL $65 \quad 100$

The Turkish teachers report that it is necessary to eliminate the lack of infrastructure and to include the students in distance education with equal opportunities in an attempt to solve the problems encountered in the distance education process. However, conducting seminars for the use of distance education materials and applications is important for the effective use of the process.

\section{DISCUSSION, CONCLUSION AND RECOMMENDATIONS}

This study was designed to examine distance education activities conducted with Turkish teachers using the semi-structured interview method. Though distance education activities have long been carried out in the world and Turkey, it is the first time distance education has continued as a longterm process in Turkey due to the Covid-19 pandemic. Students of all levels of education, parents, and educators have put effort into keeping up with this process, but lack of equal opportunities for every single student has caused some problems, which are mainly more common in Eastern and South-eastern provinces where opportunities are limited. In this respect, teachers from Siirt, a city located in the Southeast of Turkey, were interviewed while forming the study group.

Having been designed to reveal the problems experienced in the distance education process and to make suggestions for the upcoming periods, this study also encompasses the description of evaluations on Turkish teaching in distance education based on the views of 25 Turkish teachers. Within the scope of the study, teachers were first asked questions about teaching basic language skills in distance education. The related findings reveal that the main focus is on listening skills in activities during the Turkish lesson. In this respect, the research results overlap with the results of Çarkit and Koçoğlu (2020) and Karakuş et al. (2000). This is justified by the statements of teachers indicating that the most commonly used skill of students who are in front of the screen in online lessons is listening skill (Göçer, 2021: 204). In addition, it was found that the activities on speaking and reading skills were efficient, but there was a lack of concentration on writing skills. A similar study reports that writing skill is the most difficult skill for teachers in the process of language skills training through distance education (Sügüumlü, 2021: 181). In the context of research results and literature review, possible reasons for these results are as follows: teachers and students use digital literacy tools at a low level, feedback on homework is not provided properly, and control in distance education is difficult. Teachers are of the opinion that students in the South-eastern Anatolia Region also have already had problems in terms of writing and speaking skills during face-to-face 
education. Thus, to ensure these students do not fall behind in the distance education process, it is necessary to enrich the activities through the effective use of various online tools, appeal to all skills, and ensure the control of the students.

It was concluded that Zoom, EBA, and Z-book digital tools and applications were used by the teachers of Turkish teaching in distance education. In another study on distance education in Turkish teaching (Bayburtlu, 2020), it is reported that the same applications are preferred by Turkish teachers. Educational web pages and Morpa Kampüs applications are used to reinforce learning. It is reported that the Morpa Kampüs application ranks the second highly renowned and common application in Turkey after EBA, which overlaps with the results of this study (Tenekeci, 2020). The participants stated that feedback is provided using the WhatsApp application and that they can evaluate the improvement in writing skills more easily with instant feedback. Along the same lines, it was found that language activities on WhatsApp increase students' writing success scores (Gücüyeter \& İskender, 2019).

It was observed that there are various problems such as the lack of technological materials and failure to procure equal opportunities for all students, the inability to use the lesson materials effectively, the lack of an environment suitable for teaching, lack of support from parents, and the problems caused by the overuse of the system. It is predicted that most of the factors considered as disadvantages of distance education are faced in the South-eastern Anatolia Region. According to the teachers' views, those who can attend lessons were not observed to have a reduced interest in lessons. The literature review reveals that the factors affecting the distance education process negatively are the lack of necessary infrastructure, the possibility of technical problems, insufficient readiness for using the system, and access limitations arising from financial difficulties (Altıparmak, Kurt \& Kapıdere, 2011; Karadağ \& Yücel, 2020; Sezgin \& Firat, 2020).

The participants also stated that student participation increase as long as necessary opportunities are provided in distance education in Turkish teaching and that effective activities should be conducted along with the opportunities of instructional technologies to reinforce learning, and thus a positive change is expected in the students' interest and attitude towards the lesson. It is thought that distance education should be continued to support face-to-face education even after the pandemic process since it increases students' individual learning competencies and improves motivation (İskender, 2021: 110).

Switching to distance education completely with the pandemic period creates great differences in educational opportunities among the children of families who do not have sufficient opportunities or have a low economic level (Şahin, 2020; Eken, Tosun, and Eken, 2020). The findings show that Turkish teachers working in Siirt attempt to overcome such problems through videos and content designed in flash disks, which are delivered to students by hand, via WhatsApp or in communication with parents. There are problems arising from parents' insufficient levels of necessary digital literacy, which is expected to help children in distance education, as shown in other studies in the literature (Anderson, 2020; Arslan, Ar1 \& Kanat, 2021). Teachers recommend that for the general solution of the problems in teaching Turkish with distance education, technological tools should be supplied, technical problems should be solved, the quality of teaching materials should be increased, distance education seminars should be held not only for students but also for parents, and remedial teaching should be implemented to make up the shortage in education. 
In the light of the findings and conclusions obtained from the research, the following recommendations are given:

- It is recommended that the internet and tablets be provided to each student to ensure that each student has equal opportunities and full participation in classes.

- In the next stage, new methods and techniques can be found by researchers through actionoriented research as a solution to the existing problems of distance education in Turkish teaching.

- Methods and techniques that will support Turkish teaching in the distance education process can be applied primarily through a pilot scheme and then across the country by the Ministry of Education.

- Seminars for teachers, students, and parents can be held to increase the level of digital literacy by improving skills related to distance education.

\section{REFERENCES}

Altıparmak, M., Kapıdere, M. \& Kurt, İ. D. (2011, Şubat). E-öğrenme ve uzaktan eğitimde açık kaynak kodlu öğrenme yönetim sistemleri. Akademik Bilişim'11 - XIII. Akademik Bilişim Konferansında sunulan sözlü bildiri, Malatya.

Anderson, J. (2020). The coronavirus pandemic is reshaping education. Quartz Daily Brief (retrieved from https://qz.com/1826369/how-coronavirus-is-changing-education/).

Arslan, K., Arı, A. G. \& Kanat, M. H. (2021). Covid-19 pandemi sürecinde verilen uzaktan eğitim hakkında veli görüşleri. Ulakbilge Sosyal Bilimler Dergisi, 57, s. 192-206.

Ateş, M \& Sur. E. (2021). Uzaktan eğitim sürecinde türkçe eğitimi (Bölüm I: Eğitimde Dijitalleşme Dijital Okuryazarlık). Ankara: Pegem Akademi Yayıncılık.

Aziz, A. (1982). Radyo ve televizyonla eğitim. Ankara Üniversitesi Eğitim Fakültesi EFAM Yayınlar, Sevinç Matbaası.

Baxter, P. \& Jack, S. (2008). Qualitative case study methodology: Study design and implementation for novice researchers. The qualitative report, 13(4), 544-559.

Bayburtlu, Y. S. (2020). Covid-19 Pandemi Dönemi Uzaktan Eğitim Sürecinde Öğretmen Görüşlerine Göre Türkçe Eğitimi. Electronic Turkish Studies, 15(4).

Çarkıt, C \& Koçoğlu, A. (2020). Covid 19 sürecinde Türkçe dersi uygulamalarına yönelik nitel bir araştırma. International Journal of Languag' Education and Teaching, 8(4), 110-122.

Demir, E. (2014). Uzaktan eğitime genel bir bakış. Dumlupınar Üniversitesi Sosyal Bilimler Dergisi, (39), 203-212.

Eken, Ö., Tosun, N. \& Eken, D. T. (2020). Covid-19 salgını ile acil ve zorunlu uzaktan eğitime geçiş: genel bir değerlendirme. Milli Ĕ̆gitim Dergisi, 49(1), 113-128.

Gelişli, Y. (2015). Uzaktan Eğitimde Öğretmen Yetiştirme Uygulamaları: Tarihçe ve Gelişim, Journal of Research in Education and Teaching, 4 (3), 313- 321.

Göçer, A. (2021). Türkçenin uzaktan eğitimi ve öğretimi. Ankara: Pegem Akademi Yayınc1lık.

Holmberg, B. (2008). The Evolution, Principles and Practices of Distance Education. Oldenburg: BISVerlag der Carl von Ossietzky Universitat Oldenburg.

İskender, M. E. (2021). Yabancı dil olarak Türkçe öğretiminde uzaktan eğitim derslerine ilişkin deneyimler. RumeliDE Dil ve Edebiyat Araştırmaları Dergisi, (22), 96-117.

İşman, A. (2011). Uzaktan eğitim. Pegem Akademi Yayıncılık.

Karadağ, E. ve Yücel, C. (2020). Yeni tip koronavirüs pandemisi döneminde üniversitelerde uzaktan eğitim: lisans öğrencileri kapsamında bir değerlendirme çalışması. Yükseköğretim Dergisi, 1-12.

Karakuş, N., Ucuzsatar, N., Karacaoğlu, M. Ö., Esendemir, N. Ve Bayraktar, D. (2020). Türkçe 
öğretmeni adaylarının uzaktan eğitime yönelik görüşleri. Rumeli Dil ve Edebiyat Araştırmaları Dergisi, (19), 220-241.

Kaya, Z. (2002). Uzaktan eğitim. Pegem Akademi Yayıncılık.

Kırık, A. (2014). Uzaktan eğitimin tarihsel gelişimi ve Türkiye' deki durumu. Marmara İletişim Dergisi, (21), 73-94.

Merriam, S. B. (2013). Nitel araştırma: Desen ve uygulama için bir rehber (3. Baskıdan Çeviri, Çeviri Editörü: S. Turan). Ankara: Nobel Yayın Dağıtım.

Saban, A. ve Ersoy, A. (2016). Eğitimde Nitel Araştırma Desenleri, (1. Baskı) Ankara: Anı Yayınları.

Sezgin, S. ve Fırat M. (2020). Covid-19 pandemisinde uzaktan eğitime geçiş ve dijital uçurum tehlikesi. Açıöğgretim Uygulamaları ve Araştırmaları Dergisi, 6(4),37-54.

Süğümlü, Ü. (2021). A case study on teaching Turkish through distance education. International Journal of Psychology and Educational Studies, 8(1), 174-190.

Şahin, B. (2020). Salgın döneminde yürütülen çevrimiçi eğitim faaliyetleri: tespit ve öneriler raporu. Akademik-Us, 4(2), 99-101.

Usluel, Y. K. ve Mazman, S. G. (2010). Eğitimde yeniliklerin yayılımı, kabulü ve benimsenmesi sürecinde yer alan öğeler: bir içerik analizi çalışması. Çukurova Üniversitesi Eğitim Fakültesi Dergisi, 3(39), 60-74.

Yıldırım, A. ve Şimşek, H. (2013). Sosyal bilimlerde nitel araştırma yöntemleri. (9.Baskı). Ankara: Seçkin Yayıncılık.

Yin, R. (2014). Case study research: design and methods. (5. Basim). Los Angelos: Sage. 